\title{
THERAPEUTIC EFFECT OF PHYSALIS CONSUMPTION ON LIVER NECROSIS IN EXPERIMENTAL RATS
}

\author{
By

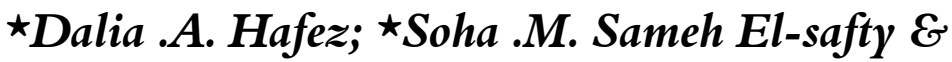 \\ $\star \star$ Ali Monahi Al-shammari
}

* Home Economics Dept, Faculty of Education, Suez University, Ismaelia Egypt.

**Home Economics Dept, Faculty of Basic Education, Public Authority for Applied and Training, State of Kuwait

\section{Research Gournal Specific Fducation \\ Faculty of Specific Fducation \\ gYansoura University}

ISSUE NO. 23, PART II, OCT. 2011

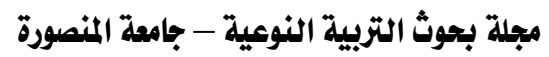

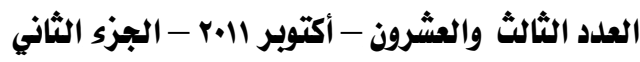


Therapeutic effect of physalis consumption on liver necrosis in experimental rats $=$ 
مجلة بحوث التربية النوعية - العدد الثالث والعشرون - يوليو | ا.r - الجزء الثاني

\title{
THERAPEUTIC EFFECT OF PHYSALIS CONSUMPTION ON LIVER NECROSIS IN EXPERIMENTAL RATS
}

\author{
$B y$
}

*Dalia .A. Hafez; *Soha .M. Sameh El-safty \& **Ali Monahi Al-shammari

* Home Economics Dept, Faculty of Education, Suez University, Ismaelia Egypt.

**Home Economics Dept, Faculty of Basic Education, Public Authority for Applied and Training, State of Kuwait

\section{Abstract}

Forty-two adult male of Sprague Dawley strain rats classified into control (-ve) group and five rat groups which administered $2 \mathrm{~g} / \mathrm{kg}$ paracetamol by stomach tube to induced liver necrosis. One of them served as control (+ve) rat group while the others were physalis powder, physalis juice, aqua physalis extract and methanol physalis extract treated rat groups. The study assigned for eight weeks.

The results showed that control (+ve) rat group showed a significant decrease in final weight, weight gain , food efficiency ratio(FER), food intake , serum high denisity lipoprotein cholesterol (HDLc), liver glutathione peroxidase (GPX), superoxide dismutase (SOD), catalase, triglyceride and glycogen. On the hand, it showed a significant increase in serum cholesterol, triglyceride, low denisity lipoprotein cholesterol (LDLc), very low denisity lipoprotein cholesterol (VLDLc), alanine aminotransferase (ALT), aspartate aminotransferase (AST), alkaline phosphatase (ALP), lactate dehydrogenase (LDH) and cholesterol/HDLc ratio. These changes were accompanied by an increase in liver malondialdehyde (MDA), cholesterol and total lipids compared to control (-ve) group.

Both physalis powder and physalis juice treated groups showed a significant decrease in final weight, weight gain, FER, liver catalase and glycogen but showed a significant increase in liver MDA and total lipids compared to control (- ve) group.

Physalis powder, physalis juice, aqua physalis extract and methanol physalis extract treated groups showed a significant increase in cholesterol/HDLc ratio, serum LDLc, ALT, AST , ALP ,LDH and liver MDA and a significant decrease in liver GPX and SOD compared to control (-ve) group. It is concluded that consumption of physalis can reduce liver damage in the experimental rats.

Key words: paracetamol - physalis- physalis extract-rats. 


\title{
THERAPEUTIC EFFECT OF PHYSALIS CONSUMPTION ON LIVER NECROSIS IN EXPERIMENTAL RATS
}

\author{
By \\ *Dalia .A. Hafez; *Soha .M. Sameh El-safty \& **Ali Monahi Al-shammari \\ * Home Economics Dept, Faculty of Education, Suez University, Ismaelia Egypt. \\ **Home Economics Dept, Faculty of Basic Education, Public Authority for Applied \\ and Training, State of Kuwait
}

\section{INTRODUCTION}

Liver is one of the largest organs in human body and involved with almost all the biochemical pathways to growth, fight against disease, nutrient supply, energy provision and reproduction. The major functions of the liver are carbohydrare, protein and fat metabolism, detoxification, secretion of bile and storage of vitamin (Ward and Daly, 1999). Liver diseases like hepatitis, cirrhosis and alcoholic liver disease are some of the fatal disease in the world today.

Paracetamol is part of the class of drugs known as aniline analgesics; it is the only such drug still in use today. It can be classified as a nonsteroidal anti-inflammatory drug (Bertolini et al., 2006). However, paracetamol acts by inhibition of prostaglandin synthesis and shows varying levels of analgesic, anti-inflammatory, antipyretic and antiplatelet actions. Acute overdoses of paracetamol can cause potentially fatal liver damage and in rare individuals. Paracetamol toxicity is the foremost cause of acute liver failure (Khashab et al., 2007).

There are not much drugs available for the treatment of liver disorders. Many folk remedies from plant origin are tested for its potential antioxidant and hepatoprotective liver damage in experimental animal model (Subramonium and Pushpangadan 1999 and Amini 2004).

The husk tomato (Physalis alkekengi var. franchetti) or ground cherry is much small fruit and can be any of a number of colors when ripe, including yellow, red, green, or even purple. Physalis is very sweet and used mainly for jam and preserves after the fruit has ripened and turned yellow. Physalis fruit is used for medicinal purposes. Physalis is reportedly commonly used to treat asthma, malaria, as a pain reliever, to treat earaches, liver problems such as hepatitis, rheumatism, gonorrhea, fever, infertility, to prevent miscarriages, and to help heal post-partum infections. It is important 
to note that the active ingredients in physalis are powerful flavonoids and alkaloids ( $\mathrm{Wu}$ et al., 2005). It is considered safe to consume, but more controlled medical research is necessary to fully establish the efficacy and safety of physalis. This study aimed to investigate the effects of physalis ( $\mathrm{P}$. alkekengi) on the diseased liver in rats.

\section{MATERIALS AND METHODS}

\section{A - Materials}

Forty-two adult male of white albino rats (Sprague Dawley Strain) weighing $125 \pm 7 \mathrm{~g}$, were obtained from of National Research Center, Cairo, Egypt. Fresh husk tomato fruits "Physalis spp was obtained from local markets in Egypt. The basal diet was prepared according to NRC (1995). Paracetamol drug, known as acetaminophen was obtained from Kahira Pharm \&Chem. Ind. Co., Cairo- Egypt. Paracetamol have ability to induce liver damage in rats by a single dose of $2 \mathrm{~g} / \mathrm{kg}$ p.o (Rafael et al., 1999).

\section{B-Methods}

Preparation of Husk tomato fruit (physalis) powder, aqua extract and methanol extract:

Husk tomato fruit (physalis) were washed with water and crushed in fresh juice or dried in air oven at $50^{\circ} \mathrm{c}$ and grinded in blender, then the powder packaged in polyethylene bags and kept until use. Physalis powder was added in basail diet as $10 \%$ in substitution of fiber. To prepare the test extract, one hundred grams of dried physalis was decocted with $1 \mathrm{~L}$ of distilled water at $65^{\circ} \mathrm{C}$ for $3 \mathrm{~h}$. The extract was filtered through filter paper and the residue was re-extracted under the same conditions. The filtrates obtained from two separate extractions were combined, concentrated and lyophilized. The dried physalis aqueous extract was collected and stored at $-21^{\circ} \mathrm{C}$ until use. To prepare the methanol extract, 100 gram of physalis powdered was added to $1000 \mathrm{ml}$ of $70 \%$ methanol (v/v) at room temperature for 20 hours with slowly rotated during this time. After filtration, ethanol was evaporated at low pressure at 30 centigrade degree (WHO 1983). The water and methanol extracts were dissolved in normal saline and was immediately administered to rats at dose $500 \mathrm{mg} / \mathrm{kg}$ body weight by stomach tube. 


\section{Experimental design}

After adaptation period (one week), the rats were randomly classified into six groups of seven rats each. The first group was a control (ve) group fed on basal diet only while the others five groups were administered paracetamol drug at a single dose of $2 \mathrm{~g} / \mathrm{kg}$ by stomach tube to induce liver necrosis(Rafael et al., 1999) then classified into

1- Control (+ve) group.

2- Physalis powder treated group.

3- Physalis juice treated group.

4- Aqua physalis extract treated group.

5- Methanol physalis extract treated group.

The food intake was calculated daily and the body weight gain was recorded weekly. Feed efficiency ratio (FER) was determined by Chapman et al., (1950) as following: FER = weight gain (g)/ food intake (g). At the end of experiment ( 8 weeks), the rats were anesthetized, blood sample were collected in clean centrifuge tubes to obtain serum. Livers were immediately removed and rinsed with saline, blotted on filter paper and stored at $-70 \mathrm{oC}$ for biochemical analyses.

Serum cholesterol, triglyceride, and high density lipoprotein (HDLc), were estimated in serum according to Allain et al., (1974), Scheletter and Nussel (1975) and Kostener (1977), respectively. Serum alanine and aspartate aminotransferase (ALT, AST) activity, alkaline phosphatase, and lactate dehydrogenase (LDH) enzymes activities were estimated according Reitman and Frankel (1957), Kind and King (1954) and Caband and Wroblewski (1958), respectively. Liver malondialdehyde (MDA), glutathione peroxidase (GPX), superoxide dismutase (SOD), and catalase levels were determined according to Draper et al., 1993, Weiss et al. (1980), Beuchamp and Fridovich (1971) and Aebi (1974), respectively. Liver cholesterol, triglyceride, total lipids and glycogen were estimated according to Abell et al., (1952), Young and Pestaner (1975), Folch et al., (1957) and Rerup and Lundquist, (1967), respectively. Very low density lipoprotein (VLDL) and low density lipoprotein were calculated according Friedewald (1972) and Fruchart (1982) as following: VLDL = (TG/5), LDL$\mathrm{c}=($ Total cholesterol - VLDL-c - HDL-c) while cholesterol /HDL-c ratio was calculated according to Castelli and levitar (1977). 


\section{C-Statistical analysis}

Collected data were subjected to analysis according to SPSS program according to Snedecor and Cochran (1967).

\section{RESULTS AND DISCUSSION}

Table (1) showed that control (+ve) rat group showed a significant decrease in final weight, weight gain and FER at $\mathrm{p}<0.001$ and also food intake at $\mathrm{p}<0.05$ compared to control (- ve) group. Both physalis powder and physalis juice treated groups showed a significant decrease in final weight $(\mathrm{p}<0.01 \& 0.05$, respectively), weight gain and FER at $\mathrm{p}<0.05$ compared to control (- ve) group. Aqua physalis extract and methanol physalis extract treated groups showed non significant difference in these parameters compared to control (- ve) group. Physalis powder, physalis juice, aqua physalis extract and methanol physalis extract treated groups showed a significant increase in final weight, weight gain, food intake and FER compared to control (+ ve) group.

Table (2) showed that control (+ve) rat group showed a significant increase in cholesterol and cholesterol/HDLc ratio but a significant decrease in HDLc at $p<0.001$ compared to control (-ve) group. Physalis juice, aqua physalis extract and methanol physalis extract treated groups showed a significant increase in cholesterol and cholesterol/HDLc ratio while physalis powder treated group showed a significant increase in cholesterol/HDLc ratio at $\mathrm{p}<0.05$ compared to control (- ve) group. Physalis powder, physalis juice, aqua physalis extract and methanol physalis extract treated groups showed a significant decrease in cholesterol and cholesterol/HDLc ratio and a significant increase in HDLc compared to control (+ ve) group.

Data in table (3) represented that control (+ve) rat group showed a significant increase in serum triglyceride, LDLc and VLDLc at $p<0.001$ compared to control (-ve) group. Physalis powder, physalis juice, aqua physalis extract and methanol physalis extract treated groups showed a significant increase in LDLc at $\mathrm{p}<0.05$ compared to control (-ve) group but showed a significant decrease in triglyceride, LDLc and VLDLc compared to control (+ve) group.

Data in table (4) showed that control (+ve) rat group showed a significant increase in serum ALT, AST, ALP and LDH at $\mathrm{p}<0.001$ while the physalis powder, physalis juice and aqua physalis extract treated groups 
showed a significant increase in serum ALT, AST and ALP at $\mathrm{p}<0.01$ and also LDH at $\mathrm{p}<0.05 \& 0.01$ compared to control (-ve) group. Methanol physalis extract treated groups showed a significant increase in serum ALT, AST and LDH at $p<0.05$ and also ALP at $p<0.01$ compared to control (-ve) group. Physalis powder, physalis juice, aqua physalis extract and methanol physalis extract treated groups showed a significant decrease in serum ALT, AST, ALP and LDH values compared to control (+ ve) group.

Data in table (5) presented that control (+ve) rat group showed a significant increase in liver MDA and a significant decrease in liver GPX, SOD and catalase at $\mathrm{p}<0.001$ while physalis powder and physalis juice showed a significant increase in liver MDA and a significant decrease in liver GPX, SOD and catalase at $\mathrm{p}<0.05$ compared to control (-ve) group. Aqua physalis extract and methanol physalis extract treated groups showed a significant increase in liver MDA and a significant decrease in liver GPX and SOD at $\mathrm{p}<0.05$ compared to control (-ve) group. Physalis powder, physalis juice, aqua physalis extract and methanol physalis extract treated groups showed a significant decrease in liver MDA and a significant increase in liver GPX, SOD and catalase compared to control (+ ve) group.

Data in table (6) presented that control (+ve) rat group showed a significant increase in liver cholesterol and total lipids at $\mathrm{p}<0.001$ but a significant decrease in liver triglyceride and glycogen at $\mathrm{p}<0.001$ compared to control (-ve) group. Physalis powder showed a significant increase in liver total lipids at $\mathrm{p}<0.05$ but a significant decrease in liver triglyceride and glycogen at $p<0.05$ while physalis juice showed a significant increase in liver total lipids at $\mathrm{p}<0.05$ and a significant decrease in liver glycogen at $\mathrm{p}<$ 0.05 compared to control (-ve) group.

Physalis powder and physalis juice treated groups showed a significant decrease in liver cholesterol and a significant increase in liver triglyceride and glycogen compared to control (+ ve) group. Aqua physalis extract and methanol physalis extract treated groups showed a significant decrease in liver cholesterol and total lipids but a significant increase in liver triglyceride and glycogen compared to control (+ ve) group.

\section{Discussion}

Literature review revealed that paracetamol hepatotoxicity is, by far, the most common cause of acute liver failure in both the United States and the United Kingdom. Paracetamol overdose results in more calls to poison 
control centers in the US than overdose of any other pharmacological substance. Untreated overdose can lead to liver failure and death within days (Larson et al., 2005).Overdoses of acetaminophen may cause toxic liver injury. Protein arylation and free radical damage due to acetaminophen metabolism have been identified as pathways leading to hepatocyte damage (Jack et al., 2010).

The use of natural products in the treatment of a variety of diseases has increased due to the considerable number of medicinal plants with proven biological activity applicable to the treatment of some diseases. Various chemical and biological investigations were carried out with these plants. Physalis is a shiny orange fruit similar in size, shape and structure to a small cherry tomato and contained in a papery husk. In regarding to nutritional results, the husk tomato fruits (Physalis) are a highly nutritious fruit. They are low in fat and contain no cholesterol or sodium and a good source of vitamins $\mathrm{A}$ and $\mathrm{C}$, beta-carotene, iron, calcium and trace amounts of $\mathrm{B}$ vitamins. There are reports of it being used as a diuretic in traditional medicine also provide an excellent source of the vitamins. Physalis possesses potent total antioxidant activities which were derived from specific flavonoids (kaempterol, quercetin, and rutin) and phenolic (caffeic acid, chlorogenic acid, cinnamic acid, and ellagic acid) compounds (Kawai et al., 2005).

The interpritoneal injections of physalis alkekengi extract decreased LDL and cholesterol concentrations significantly whereas HDL and TG plasma concentrations did not reveal any significant changes. Such changes are mainly due to the lycopene existing in the plant which is a strong antioxidant which inhibits the production of LDL and presumably increases the excretories through releasing cholesterol; therefore, it reduces blood cholesterol level and controls cholesterol synthesis (Zarei et al ., 2011).

Chemical studies have demonstrated that physalis provided hepatoprotection against oxidative damage in rats. Ellagic acid has been reported to possess activity against tetrachloride-induced hepatotoxicity in rat. Water extracts of physalis decrease in the levels of alanine and aspartate aminotransferase and alkaline phosphatase enzymes. Besides decreasing the level of lipid peroxides in the liver, also led to an increase in catalase, SOD, and GPX levels in this organ (Singh et al., 1999 and Chang et al., 2008). A crude polysaccharide extracted from Physalis alkekengi L. fruit composed 
of rhamnose, xylose, arabinose, galactose, and glucose and exhibited high scavenging effects on $\bullet \mathrm{OH}$ and DPPH radicals, and both the scavenging rates were about $80 \%$. The scavenging rate of $\bullet 02-$ radical was about $22 \%$ (Ying-kun et al., 2008).

Ethanol extract of physalis showed potent cytotoxic effect and showed potent xanthine oxidase inhibition and anti-lipid peroxidation activities. Ethanol extracts of physalis possess good antioxidant activities, and the highest antioxidant properties. At concentrations 10-100 microg/ml of ethanol physalis extract demonstrated the strongest superoxide anion scavenging and inhibitory effect on xanthine oxidase activities (Wu et al., 2005). The ethanol extract of Physalis exhibited the most potent inhibition rate on $\mathrm{FeCl} 2$-ascorbic acid induced lipid peroxidation in rat liver homogenate and act as strongest superoxide anion scavenging and inhibitory effect on xanthine oxidase activities (Sue-Jing et al., 2005). Water, ethanol and hexane extracts of Physalis peruviana $(500 \mathrm{mg} / \mathrm{kg}$ body weight) showed antihepatotoxic activities against $\mathrm{CCl} 4$ induced hepatotoxicity. The ethanol and hexane extracts showed moderate activity compared to water extract, which showed activity at a low dose of $125 \mathrm{mg} / \mathrm{kg}$. The extract administration to rats resulted in an increase in hepatic glutathione and decrease in MDA. Preliminary phytochemical analysis revealed the presence of various components in the crude aqueous extract (Arun and Asha 2007). Daily intake of Physalis angulata extract in rats results in an increase in antioxidant enzyme activity and HDL-cholesterol, and a decrease in malondialdehyde, which may reduce the risk of inflammatory and heart disease (Choi and Hwang 2005). It is concluded that consumption of physalis has antihepatotoxic activity and improve functions of the injured liver. 


\section{REFERENCE}

- Abell, L.L., Levy, B.B., Brodie, B.B. and Kendal, R. (1952): A simplified method for the estimation of total cholesterol in serum and demonstration of its specificity. J .Biol .Chem, 357-366.

- Aebi, H.E. (1974): Catalase, second ed. In: Bergmeyer, H.U. (Ed.), Methods in Enzymatic Analysis, vol. 3. Verlagchemic, Weinheim, 673-684.

- Allain, C.C., Richmond, N. and Rosechloy, P. (1974): Cholesterol enzymatic colorimetric test. Clin. Chem., 19 (20): 1350-470.

- Amini A. (2004): Dictionary of therapeutic plants. Tehran University, Tehran, 157-159.

- Arun,M. and Asha, V.V. (2007): Preliminary studies on antihepatotoxic effect of Physalis peruviana Linn. (Solanaceae) against carbon tetrachloride induced acute liver injury in rats. $\mathrm{J}$ Ethnopharmacol. Apr 20;111(1):110-4.

- Bertolini, A., Ferrari, A., Ottani, A., Guerzoni, S., Tacchi, R.and Leone, S. (2006): Paracetamol: new vistas of an old drug. CNS drug reviews, 12 (3-4): 250-75.

- Beuchamp, C and Fridovich, J. (1971): Superoxide dismutase. Improved an assay applicable to acrylamide gels. Anal Biochem.44:276-287.

- Caband, P. and Wroblewski, F. (1958):Colorimetric measurement of lactic dehydrogenase activity of body fluids .Am J Clin Pathol,30:234.

- Castelli, T and levitar, Y. (1977): Atherogenic index, Curr presc P. 39.

- Chang, J.C., Lin, C.C., Wu, S.J., Lin, D.L., Wang, S.S., Miaw, C.L. and Ng, L.T. (2008): Antioxidative and hepatoprotective effects of physalis peruviana extract against acetaminophen-induced liver injury in rats. Pharmaceutical Biology, Vol. 46, Nos. 10-11, 724-731.

- Chapman, D.G., Gastilla R. and Campbell, T.A. (1950): Evaluation of protein in food. I. A. Method for the determination of protein efficiency ratio. Can. J. Biochem. Physio. I (37) 679-686.

- Choi, E.M. and Hwang,J.K. (2005): Effect of some medicinal plants on plasma antioxidant system and lipid levels in rats. Phytother Res, May; 19(5):382-6.

- Draper, H.H., Squires, E.J., Mahmoodi, H., Wu, J., Agarwal, S.and Hadley, M., (1993): A comparative evaluation of thiobarbituric acid methods for the determination of malondialdehyde in biological material. Free Radic. Biol. Med. 15, 353-363.

- Folch, J., lees, M. and Stanley, G.H. (1957): A simple method for isolation and purification of total lipid from animal tissue. J Biol Chem 266: 497-509. 
- Friedewald, W.T., Levy, R.I. and Fredrickson, D.S. (1972): Estimation of the concentration of low-density lipoprotein cholesterol in plasma, without use of the preparative ultracentrifuge. Clin Chem 18, 499-502.

- Fruchart, G.G. (1982): LDL-Cholesterol determination after separation of low density lipoprotein. Rev. Fr. Des. Laboratories, 103: 7:117.

- Jack, A., Dean, W. and Laura, P. (2010): Mechanisms of AcetaminophenInduced Liver Necrosis. Adverse Drug Reactions Handbook of Experimental Pharmacology, 196(3), 369-405.

- Kawai, M., Yamamoto, T., Makino, B., Yamamura, H., Araki, S., Butsugan, Y. and Saito, K. (2001): The structure of physalin $\mathrm{T}$ from Physalis alkekengi var. franchetti. Journal of Asian natural products research, 3 (3): 199-205.

- Khashab, M., Tector, A.J. and Kwo, P.Y. (2007): Epidemiology of acute liver failure. Curr Gastroenterol Rep, March 9 (1): 66-73.

- Kind, P.R and King, E.J. (1954): Estimation of alkaline phosphatase activity by determination of hydrolyzed phenol with aminoantipyrene. J. Clin.Path.7, 322.

- Kostener, C. M. (1977): Enzymatic determination of cholesterol high density lipoprotein fraction prepared by polyanion precipitation. J. Clin. Chem., 22:695.

- Larson, A.M., Polson, J. and Fontana, R.J. (2005): Acetaminophen-induced acute liver failure: results of a United States multicenter, prospective study. Hepatology, Dec, 42 (6): 1364-72.

- NRC (1995): National Research council: Nutrient requirements of laboratory animals. Fourth revised edition, PP.29-30 National Academy Press. Washington, DC.

- Rafael, B., Daniela, F., Haim, S., Hussein, A., Zipora, M, Moshe, P., Liliana, Z., Yona, A., Ran, O. and Zamir, H.(1999):Hypothyroidism Protects Rat Liver from Acetaminophen Hepatotoxicity. Digestive Diseases and Sciences , 44(6): 1228-1235.

- Reitman, S. and Frankel, S. (1957): Enzymatic determination of liver function. Am.J.Clin. path., 28:56-63.

- Rerup , E. and Lundquist, S. (1967): Precipitation and purification of liver glycogen in rats .Acta Pharmmic. Tox. 25:47-51.

- Scheletter G. and Nussel, E. (1975): Arbeitsmed Sozialmed praventimed, 10-25.

- Singh, K., Khanna, A.K. and Chander, R. (1999): Hepatoprotective activity of ellagic acid against carbon tetrachloride induced hepatotoxicity in rats. Indian J Exp Biol, 37: 1025-1026.

- Snedecor,G.W. and Cochran,W.G. (1967):Statistical methods .6 ${ }^{\text {th }}$ ed. Iowa State Univ.,Press Iowa Ames USA 
- Subramonium, A. and Pushpangadan, P. (1999): Development of Phytomedicines for liver diseases. Indian J. Pharmacol, 31, pp. 166-175

- Sue-Jing, W.U., Lean-Teik, N.G., Yuan-Man, H. ,Doung-Liang, L. and ShyhShyan, W., Shan-Ney H. and Chun-Ching, L.(2005): Antioxidant Activities of Physalis peruviana Biol. Pharm. Bull, 28(6) 963-966.

- Ward, F.M. and Daly, M.J. (1999): Hepatic Disease. In: Clinical Pharmacy and Therapeutics (Walker R.and C.Edwards Eds.). Churchill Livingstone, New York. pp. 195-212.

- Weiss, C., Marker, H.S. and Lehrer, G.M. (1980): Sensitive fluorometric assays for glutathione peroxidase and reductase. Anal Biochem 106: 512-516.

- WHO (1983): Protocol CG-04: Preparation of alcoholic extract for bioassay and phytochemical studies (APJF/IP, 1001A). Geneva, World Health Organization.

- Wu, S.J. , Ng, L.T., Huang, Y.M., Lin, D.L., Wang, S.S., Huang, S.N. and Lin, C.C.(2005):Antioxidant activities of Physalis peruviana. Biol Pharm Bull. Jun; 28(6):963-6.

- Ying-kun, C., Lei, L., Zhao-kun, M., A-li, H., Yu-jie, W. and Li-rong, T. (2008): Component analysis and free radicals scavenging activity. Chemical Research in Chinese Universities, 24(2), 167-170.

- Young, A. and Pestaner, D.L. (1975): Determination of triglycerides in serum .Clin.Chem. 21:5-7.

- Zarei, A.1., Ashtiyani, S.C., Rasekh, F., Mohammadi, A. and Jabary, A. (2011): The effects of Physalis Alkekengi extract on lipids concentrations in rats. Arak Medical University Journal (AMUJ), 14(55): 36-42. 
Table (1): Mean values \pm SD of body weight gain, food intake and food efficiency ratio (FER) of the experimental rat groups

\begin{tabular}{|c|c|c|c|c|c|c|}
\hline \multirow{2}{*}{$\begin{array}{c}\text { Groups } \\
\text { Variables }\end{array}$} & \multirow{2}{*}{$\begin{array}{c}\text { Control } \\
\text { (-ve) }\end{array}$} & \multirow{2}{*}{$\begin{array}{c}\text { Contro } \\
1 \\
(+v e)\end{array}$} & \multicolumn{4}{|c|}{ Physalis } \\
\hline & & & powder & juice & $\begin{array}{c}\text { aqua } \\
\text { extract }\end{array}$ & $\begin{array}{c}\text { methanolic } \\
\text { extract }\end{array}$ \\
\hline $\begin{array}{c}\text { Initial } \\
\text { Weight(g) }\end{array}$ & $\begin{array}{c}125.33 \pm \\
3.17^{\mathrm{a}}\end{array}$ & $\begin{array}{c}127.41 \pm \\
3.21^{\mathrm{a}}\end{array}$ & $\begin{array}{c}128.36 \pm \\
3.11^{a}\end{array}$ & $\begin{array}{c}125.55 \pm \\
2.99^{\mathrm{a}}\end{array}$ & $\begin{array}{c}126.61 \pm \\
2.88^{\mathrm{a}}\end{array}$ & $\begin{array}{c}126.71 \pm \\
3.16^{\mathrm{a}}\end{array}$ \\
\hline $\begin{array}{c}\text { Final } \\
\text { Weight }(g)\end{array}$ & $\begin{array}{c}217.31 \pm \\
7.21^{\mathrm{a}}\end{array}$ & $\begin{array}{l}156.34 \pm \\
3.61^{\mathrm{c}^{* * * *}}\end{array}$ & $\begin{array}{c}193.21 \pm \\
5.21^{b^{* * * *}}\end{array}$ & $\begin{array}{c}191.21 \pm \\
5.11^{b^{*}}\end{array}$ & $\begin{array}{c}207.18 \pm \\
6.81^{a}\end{array}$ & $\begin{array}{c}210.14 \pm \\
5.66^{\mathrm{a}}\end{array}$ \\
\hline $\begin{array}{l}\text { Weight } \\
\text { gain (g) }\end{array}$ & $\begin{array}{r}\text { 91.98 } \\
8.17^{\mathrm{a}} \\
\end{array}$ & $\begin{array}{l}28.93 \pm \\
3.21^{\mathbf{c}^{* * * *}}\end{array}$ & $\begin{array}{c}64.85 \pm \\
6.11^{b^{*}}\end{array}$ & $\begin{array}{r}65.66 \pm \\
5.99^{b^{*}}\end{array}$ & $\begin{array}{r}80.57 \pm \\
6.71^{a} \\
\end{array}$ & $\begin{array}{r}83.43 \pm \\
6.66^{a} \\
\end{array}$ \\
\hline $\begin{array}{c}\text { Food } \\
\text { intake }(g / w)\end{array}$ & $\begin{array}{c}17.15 \pm \\
1.33^{\mathrm{a}} \\
\end{array}$ & $\begin{array}{l}13.18 \pm \\
1.20^{b^{*}} \\
\end{array}$ & $\begin{array}{c}16.31 \pm \\
1.51^{\mathrm{a}} \\
\end{array}$ & $\begin{array}{c}15.93 \pm \\
1.43^{\mathrm{a}} \\
\end{array}$ & $\begin{array}{c}16.67 \pm \\
1.56^{a} \\
\end{array}$ & $\begin{array}{r}16.86 \pm \\
1.62^{a} \\
\end{array}$ \\
\hline FER & $\begin{array}{l}0.089 \pm \\
0.001^{a}\end{array}$ & $\begin{array}{c}\mathbf{0 . 0 3 4} \pm \\
\mathbf{0 . 0 0 3}^{\mathbf{d}^{* * *}}\end{array}$ & $\begin{array}{l}0.066 \pm \\
0.002^{c^{*}}\end{array}$ & $\begin{array}{l}0.068 \pm \\
0.001^{c^{*}}\end{array}$ & $\begin{array}{c}0.080 \pm \\
0.002^{\text {ab }}\end{array}$ & $\begin{array}{l}0.082 \pm \\
0.004^{\text {ab }}\end{array}$ \\
\hline
\end{tabular}

Significant with control group $* \mathbf{P}<0.05 * * \quad \mathbf{P}<0.01 * * * \mathbf{P}<0.001$

Mean values in each raw having different superscript $(a, b, c, d)$ are significant

Table (2): The Mean values \pm SD of serum cholesterol, HDLc and cholesterol/ HDLc ratio of the experimental rat groups

\begin{tabular}{|c|c|c|c|c|c|c|}
\hline \multirow{2}{*}{$\begin{array}{c}\text { Groups } \\
\text { Variables }\end{array}$} & \multirow{2}{*}{$\begin{array}{c}\text { Control } \\
\text { (-ve) }\end{array}$} & \multirow{2}{*}{$\begin{array}{l}\text { Control } \\
(+\mathbf{e})\end{array}$} & \multicolumn{4}{|c|}{ Physalis } \\
\hline & & & powder & juice & $\begin{array}{c}\text { aqua } \\
\text { extract }\end{array}$ & $\begin{array}{c}\text { methanolic } \\
\text { extract }\end{array}$ \\
\hline $\begin{array}{c}\text { Cholesterol } \\
(\mathrm{mg} / \mathrm{g})\end{array}$ & $\begin{array}{c}95.80 \pm \\
9.24^{\mathrm{c}}\end{array}$ & $\begin{array}{l}155.31 \pm \\
11.88^{\mathrm{a}^{* * * *}}\end{array}$ & $\begin{array}{c}103.61 \pm \\
8.14^{\text {bc }}\end{array}$ & $\begin{array}{c}110.32 \pm \\
8.61^{b^{*}}\end{array}$ & $\begin{array}{l}112.31 \pm \\
10.21^{b^{*}}\end{array}$ & $\begin{array}{c}107.24 \pm \\
9.81^{b^{*}}\end{array}$ \\
\hline $\begin{array}{l}\text { HDLc } \\
(\mathrm{mg} / \mathrm{g})\end{array}$ & $\begin{array}{c}35.61 \pm \\
3.33^{a}\end{array}$ & $\begin{array}{l}22.67 \pm \\
3.11^{b^{* * * *}}\end{array}$ & $\begin{array}{c}31.24 \pm \\
3.21^{\mathrm{a}}\end{array}$ & $\begin{array}{c}\text { 30.21 } \pm \\
3.10^{\mathrm{a}}\end{array}$ & $\begin{array}{c}\text { 31.81 } \pm \\
4.01^{\mathrm{a}}\end{array}$ & $\begin{array}{c}33.61 \pm \\
3.27^{\mathrm{a}}\end{array}$ \\
\hline $\begin{array}{c}\text { Cholesterol } \\
\text { / HDLc }\end{array}$ & $\begin{array}{l}2.69 \pm \\
0.14^{\mathrm{c}}\end{array}$ & $\begin{array}{c}6.85 \pm \\
0.55^{a^{* * *}}\end{array}$ & $\begin{array}{l}3.31 \pm \\
0.24^{b^{*}}\end{array}$ & $\begin{array}{l}3.65 \pm \\
0.43^{b^{*}}\end{array}$ & $\begin{array}{l}3.53 \pm \\
0.46^{b^{*}} \\
\end{array}$ & $\begin{array}{c}\text { 3.19士 } \\
0.33^{b^{*}}\end{array}$ \\
\hline
\end{tabular}

Significant with control group $* \mathbf{P}<0.05 * * \quad \mathbf{P}<0.01 * * * \mathbf{P}<0.001$

Mean values in each raw having different superscript $(a, b, c, d)$ are significant 
مجلة بحوث التربية النوعية - العلد الثالث والعشرون - يوليو | ا.r - الجزء الثاني

Table (3): The Mean values \pm SD of serum triglyceride, LDLc and VLDLc of the experimental rat groups

\begin{tabular}{|c|c|c|c|c|c|c|}
\hline \multirow{2}{*}{$\begin{array}{c}\text { Groups } \\
\text { Variables }\end{array}$} & \multirow{2}{*}{$\begin{array}{c}\text { Control } \\
\text { (-ve) }\end{array}$} & \multirow{2}{*}{$\begin{array}{c}\text { Control } \\
\text { (+ve) }\end{array}$} & \multicolumn{4}{|c|}{ Physalis } \\
\hline & & & powder & juice & $\begin{array}{c}\text { aqua } \\
\text { extract }\end{array}$ & $\begin{array}{c}\text { methanolic } \\
\text { extract }\end{array}$ \\
\hline $\begin{array}{c}\text { Triglyceride } \\
\text { (mg/g) }\end{array}$ & $\begin{array}{c}75.87 \pm \\
5.61^{b}\end{array}$ & $\begin{array}{l}125.60 \pm \\
12.13^{a^{* * * *}}\end{array}$ & $\begin{array}{c}83.77 \pm \\
8.67^{b}\end{array}$ & $\begin{array}{c}85.61 \pm \\
9.01^{b}\end{array}$ & $\begin{array}{c}86.71 \pm \\
8^{6.11^{b}}\end{array}$ & $\begin{array}{c}80.14 \pm \\
9.03^{b}\end{array}$ \\
\hline $\begin{array}{l}\text { LDLc } \\
(\mathrm{mg} / \mathrm{g})\end{array}$ & $\begin{array}{r}45.08 \pm \\
5.11^{\mathrm{c}}\end{array}$ & $\begin{array}{l}107.52 \pm \\
10.22^{a^{* * * *}}\end{array}$ & $\begin{array}{l}55.62 \pm \\
6.17^{b^{*}}\end{array}$ & $\begin{array}{l}62.99 \pm \\
7.29^{b^{*}}\end{array}$ & $\begin{array}{l}63.16 \pm \\
7.03\end{array}$ & $\begin{array}{l}\mathbf{5 7 . 6 1 \pm} \\
\mathbf{5 . 6 7}^{\mathbf{b}^{*}}\end{array}$ \\
\hline $\begin{array}{l}\text { VLDLc } \\
\text { (mg/dl) }\end{array}$ & $\begin{array}{c}15.11 \pm \\
1.36^{b}\end{array}$ & $\begin{array}{l}25.12 \pm \\
2.11^{\mathrm{a}^{* * * * *}}\end{array}$ & $\begin{array}{c}16.75 \pm \\
1.60^{b}\end{array}$ & $\begin{array}{c}17.12 \pm \\
1.81^{b}\end{array}$ & $\begin{array}{c}17.34 \pm \\
1.71^{b}\end{array}$ & $\begin{array}{c}16.02 \pm \\
1.65^{b}\end{array}$ \\
\hline
\end{tabular}

Significant with control group $* \mathbf{P}<0.05 * * \quad \mathbf{P}<0.01 * * * \mathbf{P}<0.001$

Mean values in each raw having different superscript $(a, b, c, d)$ are significant

Table (4): The Mean values \pm SD of serum amino transferase (ALT \& AST), alkaline phosphatase enzymes (ALP) and lactic dehydrogenase (LDH) of the experimental rat groups

\begin{tabular}{|c|c|c|c|c|c|c|}
\hline \multirow{2}{*}{$\begin{array}{c}\text { Groups } \\
\text { Variables }\end{array}$} & \multirow{2}{*}{$\begin{array}{c}\text { Control } \\
\text { (-ve) }\end{array}$} & \multirow{2}{*}{$\begin{array}{c}\text { Control } \\
(+\mathbf{e})\end{array}$} & \multicolumn{4}{|c|}{ Physalis } \\
\hline & & & powder & juice & $\begin{array}{c}\text { aqua } \\
\text { extract }\end{array}$ & $\begin{array}{c}\text { methanolic } \\
\text { extract }\end{array}$ \\
\hline $\begin{array}{c}\text { ALT } \\
(\boldsymbol{\mu} / \mathbf{m l})\end{array}$ & $\begin{array}{c}45.33 \pm \\
5.22^{\mathrm{e}}\end{array}$ & $\begin{array}{l}155.66 \pm \\
15.16^{a^{* * * *}} \\
\end{array}$ & $\begin{array}{l}99.61 \pm \\
9.21^{b^{* *}}\end{array}$ & $\begin{array}{l}103.21 \pm \\
10.21^{b * *}\end{array}$ & $\begin{array}{l}85.61 \pm \\
9.15^{c^{* * *}}\end{array}$ & $\begin{array}{l}68.14 \pm \\
6.18^{d *} \\
\end{array}$ \\
\hline $\begin{array}{c}\text { AST } \\
(\mu / \mathrm{ml})\end{array}$ & $\begin{array}{c}65.21 \pm \\
6.28^{d} \\
\end{array}$ & $\begin{array}{l}193.21 \pm \\
13.12^{\mathrm{a}^{* * * *}}\end{array}$ & $\begin{array}{l}141.21 \pm \\
11.10^{b^{* *}}\end{array}$ & $\begin{array}{l}149.65 \pm \\
12.15^{b * *}\end{array}$ & $\begin{array}{l}137.21 \pm \\
11.03^{b * *}\end{array}$ & $\begin{array}{c}89.16 \pm \\
9.10^{c^{*}} \\
\end{array}$ \\
\hline $\begin{array}{c}\mathbf{A L P} \\
(\mu / \mathrm{ml})\end{array}$ & $\begin{array}{c}75.71 \pm \\
7.17\end{array}$ & $\begin{array}{l}170.13 \pm \\
15.15^{\mathrm{a}^{* * * * *}}\end{array}$ & $\begin{array}{l}105.71 \pm \\
10.22^{b^{* * *}}\end{array}$ & $\begin{array}{l}110.14 \pm \\
11.13 b^{b^{* *}}\end{array}$ & $\begin{array}{l}\text { 108.31士 } \\
9.21^{b^{* * *}}\end{array}$ & $\begin{array}{l}98.71 \pm \\
9.11^{b^{* * *}}\end{array}$ \\
\hline $\begin{array}{c}\text { LDH } \\
(\mathbf{I u} / \mathbf{m l})\end{array}$ & $\begin{array}{c}130.31 \pm \\
13.21 \\
\end{array}$ & $\begin{array}{c}277.71 \pm \\
23.20^{a^{* * * *}} \\
\end{array}$ & $\begin{array}{l}173.31 \pm \\
17.21^{b^{* * *}}\end{array}$ & $\begin{array}{l}181.14 \pm \\
20.12^{b^{*}}\end{array}$ & $\begin{array}{l}170.31 \pm \\
17.31^{b *}\end{array}$ & $\begin{array}{l}161.31 \pm \\
15.77^{b^{*}}\end{array}$ \\
\hline
\end{tabular}

Significant with control group $* \mathbf{P}<0.05 * * \quad \mathbf{P}<0.01 * * * \mathbf{P}<0.001$

Mean values in each raw having different superscript $(a, b, c, d)$ are significant 
Therapeutic effect of physalis consumption on liver necrosis in experimental rats $=$

Table (5): The Mean values \pm SD of some liver malondialdehyde (MDA) glutathione peroxidase (GPX), superoxide dismutase (SOD) and catalase of the experimental rat groups

\begin{tabular}{|c|c|c|c|c|c|c|}
\hline \multirow{2}{*}{$\begin{array}{c}\text { Groups } \\
\text { Variables }\end{array}$} & \multirow{2}{*}{$\begin{array}{c}\text { Control } \\
\text { (-ve) }\end{array}$} & \multirow{2}{*}{$\begin{array}{c}\text { Control } \\
\text { (+ve) }\end{array}$} & \multicolumn{4}{|c|}{ Physalis } \\
\hline & & & powder & juice & $\begin{array}{c}\text { aqua } \\
\text { extract }\end{array}$ & $\begin{array}{c}\text { methanolic } \\
\text { extract }\end{array}$ \\
\hline $\begin{array}{c}\text { MDA } \\
(\mathrm{mmol} / \mathrm{g})\end{array}$ & $\begin{array}{l}18.3 \pm \\
2.14^{\mathrm{c}}\end{array}$ & $\begin{array}{l}\text { 40.31士 } \\
4.21^{\mathrm{a}^{* * * *}}\end{array}$ & $\begin{array}{c}29.17 \pm \\
3.61^{b^{*}}\end{array}$ & $\begin{array}{l}23.16 \pm \\
2.99^{b^{*}}\end{array}$ & $\begin{array}{l}25.80 \pm \\
3.11^{b^{*}}\end{array}$ & $\begin{array}{l}26.37 \pm \\
4.03\end{array}$ \\
\hline $\begin{array}{c}\text { GPX } \\
(\mu / \mathbf{m g})\end{array}$ & $\begin{array}{l}122.14 \pm \\
14.13^{\mathrm{a}}\end{array}$ & $\begin{array}{l}35.77 \pm \\
6.211^{\text {d***** }}\end{array}$ & 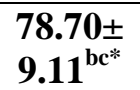 & $\begin{array}{l}89.14 \pm \\
0.21^{b^{*}}\end{array}$ & $\begin{array}{l}85.36 \pm \\
9.21^{b^{*}}\end{array}$ & $\begin{array}{l}92.11 \pm \\
10.21^{b^{*}}\end{array}$ \\
\hline $\begin{array}{c}\text { SOD } \\
(\mu / m g)\end{array}$ & $\begin{array}{c}110.71 \pm \\
11.35^{\mathrm{a}}\end{array}$ & $\begin{array}{l}45.91 \pm \\
5.71^{\text {c }^{* * * *}}\end{array}$ & $\begin{array}{c}89.21 \pm \\
8.36^{b *}\end{array}$ & $\begin{array}{l}91.14 \pm \\
10.22^{b *}\end{array}$ & $\begin{array}{c}\text { 88.31士 } \\
9.11^{b^{*}}\end{array}$ & $\begin{array}{l}90.14 \pm \\
8.31^{b *}\end{array}$ \\
\hline $\begin{array}{c}\text { Catalase } \\
(\mu / \mathrm{mg} \text { protein })\end{array}$ & $\begin{array}{r}97.87 \pm \\
8.67^{a} \\
\end{array}$ & $\begin{array}{l}\text { 33.11士 } \\
4.21^{\mathrm{c}^{* * * *}}\end{array}$ & $\begin{array}{c}80.16 \pm \\
8^{8.31} 1^{b^{*}} \\
\end{array}$ & $\begin{array}{l}87.21 \pm \\
9.61^{b^{*}}\end{array}$ & $\begin{array}{l}91.61 \pm \\
11.14^{\text {ab }} \\
\end{array}$ & $\begin{array}{c}101.14 \pm \\
10.21^{\mathrm{a}}\end{array}$ \\
\hline
\end{tabular}

Significant with control group $* \mathbf{P}<0.05 * * \quad \mathbf{P}<0.01 * * * \mathbf{P}<0.001$

Mean values in each raw having different superscript $(a, b, c, d)$ are significant.

Table (6): The Mean values \pm SD of some liver cholesterol, triglyceride, and total lipids and glycogen of the experimental rat groups

\begin{tabular}{|c|c|c|c|c|c|c|}
\hline \multirow{2}{*}{$\begin{array}{c}\text { Groups } \\
\text { Variables }\end{array}$} & \multirow{2}{*}{$\begin{array}{c}\text { Control } \\
\text { (-ve) }\end{array}$} & \multirow{2}{*}{$\begin{array}{c}\text { Control } \\
(+\mathrm{ve})\end{array}$} & \multicolumn{4}{|c|}{ Physalis } \\
\hline & & & powder & juice & $\begin{array}{c}\text { aqua } \\
\text { extract }\end{array}$ & $\begin{array}{c}\text { methanolic } \\
\text { extract }\end{array}$ \\
\hline $\begin{array}{c}\text { Cholesterol } \\
(\mathrm{mg} / \mathrm{g})\end{array}$ & $\begin{array}{l}4.55 \pm \\
0.77^{b}\end{array}$ & $\begin{array}{l}7.57 \pm \\
1.14^{a^{* * *}}\end{array}$ & $\begin{array}{l}5.55 \pm \\
0.75^{b}\end{array}$ & $\begin{array}{l}5.35 \pm \\
0.85^{b}\end{array}$ & $\begin{array}{l}5.11 \pm \\
0.63^{b}\end{array}$ & $\begin{array}{l}5.22 \pm \\
0.43^{b}\end{array}$ \\
\hline $\begin{array}{c}\text { Triglyceride } \\
\text { (mg/g) }\end{array}$ & $\begin{array}{l}3.41 \pm \\
0.40^{\mathrm{a}} \\
\end{array}$ & $\begin{array}{c}1.66 \pm \\
0.13^{c^{* * * *}}\end{array}$ & $\begin{array}{l}2.44 \pm \\
0.64^{b^{*}} \\
\end{array}$ & $\begin{array}{l}2.66 \pm \\
0.72^{a b}\end{array}$ & $\begin{array}{l}2.71 \pm \\
0.53^{a b} \\
\end{array}$ & $\begin{array}{l}2.55 \pm \\
0.22^{a b}\end{array}$ \\
\hline $\begin{array}{c}\text { Total lipids } \\
(\mathrm{mg} / \mathrm{g})\end{array}$ & 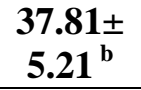 & $\begin{array}{l}\text { 45.17士 } \\
4.10^{a^{* * *}} \\
\end{array}$ & $\begin{array}{l}\text { 40.31士 } \\
4.11^{a^{*}} \\
\end{array}$ & $\begin{array}{l}41.55 \pm \\
5.11^{a^{*}}\end{array}$ & 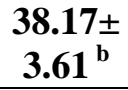 & $\begin{array}{c}38.36 \pm \\
3.21^{\mathrm{b}} \\
\end{array}$ \\
\hline $\begin{array}{l}\text { Glycogen } \\
(\mathrm{mg} / \mathbf{1 0 0 g})\end{array}$ & $\begin{array}{l}8.91 \pm \\
1.71^{\mathrm{a}}\end{array}$ & $\begin{array}{c}4.88 \pm \\
0.88^{\mathrm{c}^{* * * *}}\end{array}$ & $\begin{array}{l}6.11 \pm \\
1.51^{b^{*}}\end{array}$ & $\begin{array}{l}6.36 \pm \\
1.31^{b^{*}}\end{array}$ & $\begin{array}{l}7.01 \pm \\
1.21^{\mathrm{ab}}\end{array}$ & $\begin{array}{l}7.31 \pm \\
1.14^{a b}\end{array}$ \\
\hline
\end{tabular}

Significant with control group $* \mathbf{P}<0.05 * * \quad \mathbf{P}<0.01 * * * \mathbf{P}<0.001$

Mean values in each raw having different superscript $(a, b, c, d)$ are significant. 


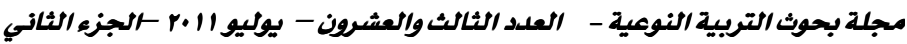

\section{التأثير العلاجي لتناول الحرنكش على تلف خلايا الكبد في فئران التجارب}

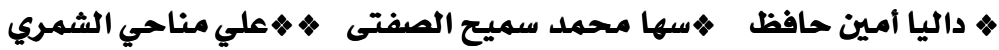

• قسـم الاقتصـاد المــزلي- كليه التربية- جامعـه قنـاة السـويس- الاسماعلية - مصـر.

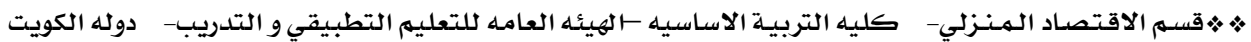

\section{ט่il|}

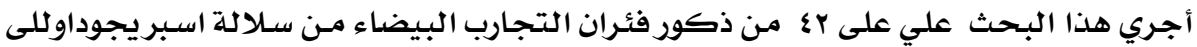

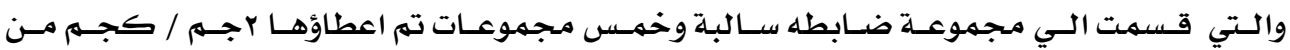

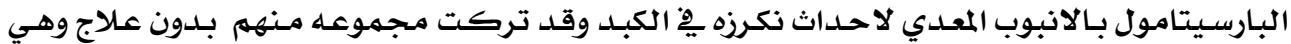

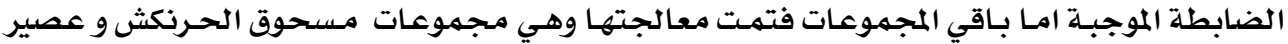

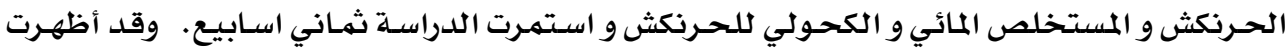

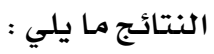

ان المجموعـة الضابطة الموجبـة أظهرت انخفـاض معنـوي يِّا الوزن النهائي و المكتسب ومعامـل

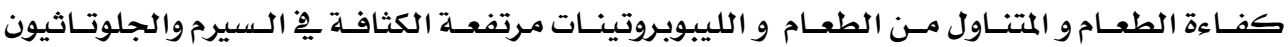

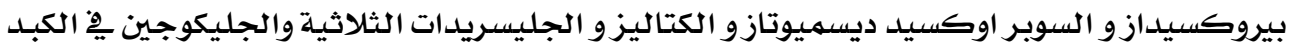

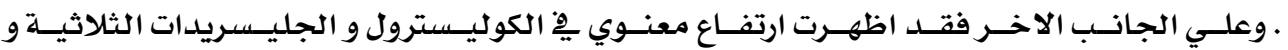

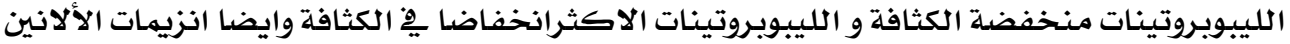

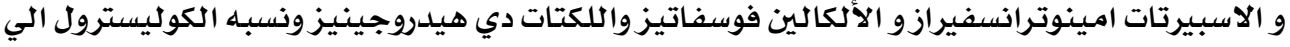

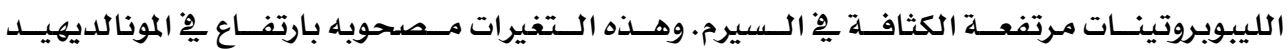

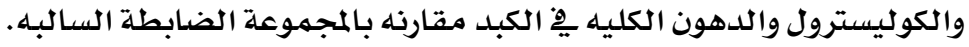
وقد اظهرت مجموعتا مسحوق وعصير الحرنكث انخفاض معنوي يِ الوزن النهائي و المكتسب

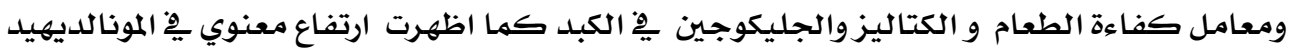

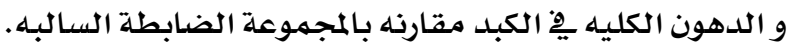

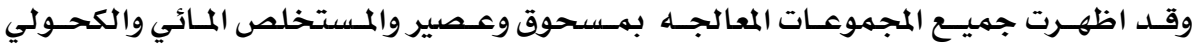

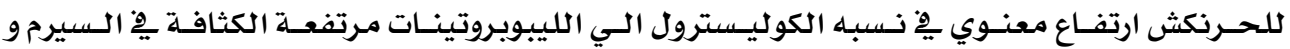

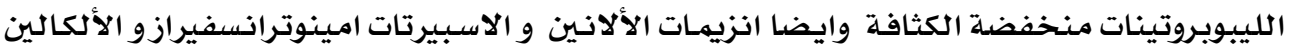

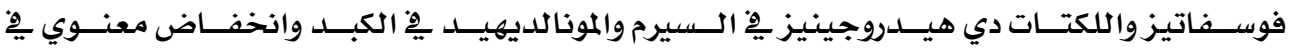

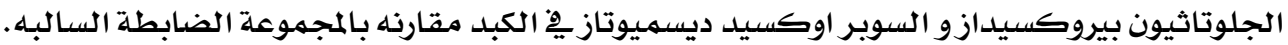
ومن ذلك نستتنج ان تناول الحرنكث يخفض من تلف الكبد يٌْ فئران التجارب. 